\section{Figure S2}

$\times$ Transitions (S)

$\triangle$ Transversions (V)
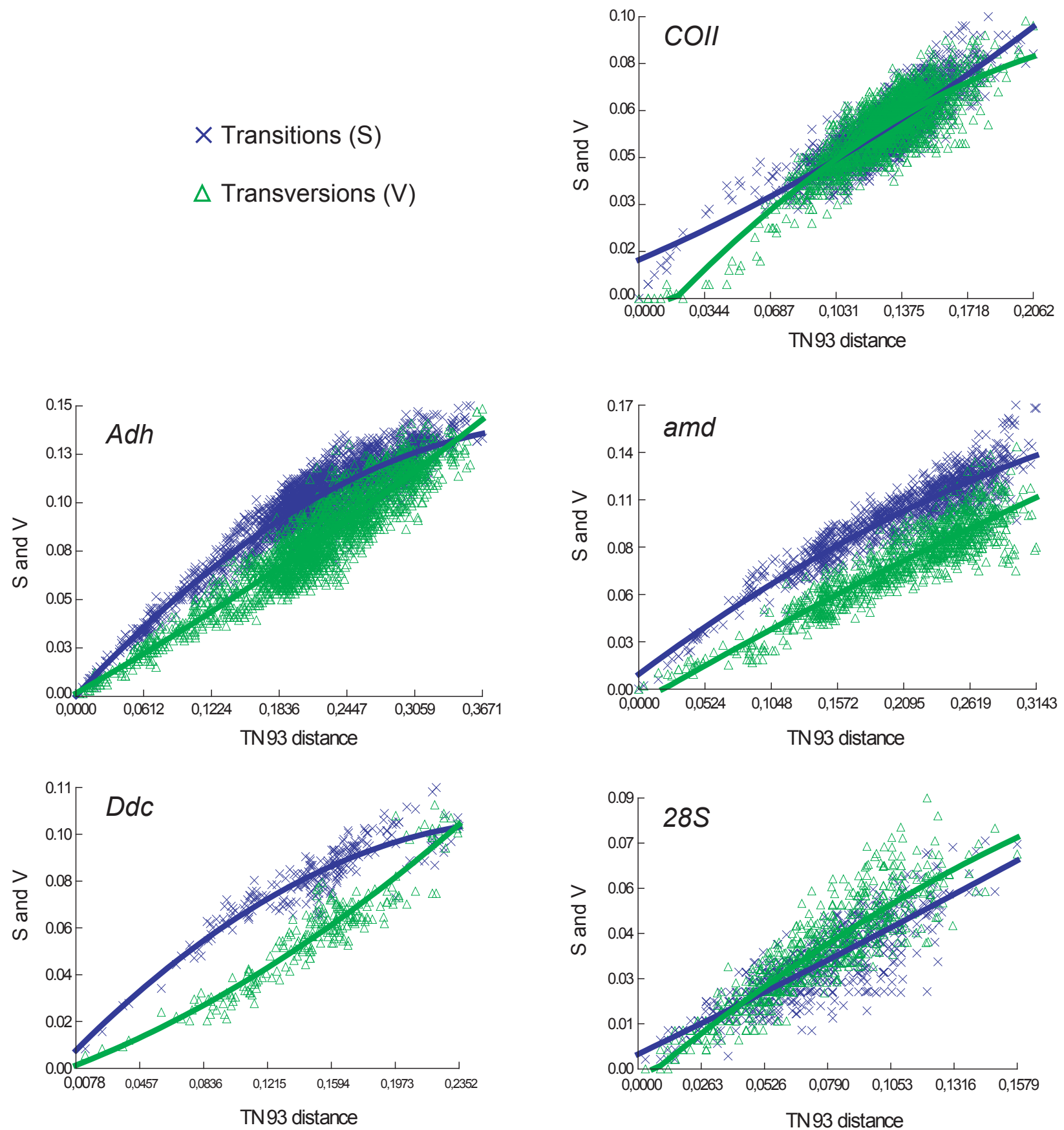